\title{
Uji Validasi Kadar Interleukin-4 (IL-4) Sebagai Alternatif Uji Diagnosis Infeksi Kecacingan
}

\author{
Ike Hermawati, ${ }^{1}$ Herry Herman, ${ }^{2}$ Ridad Agoes $^{3}$ \\ ${ }^{1}$ STIKes A. Yani Cimahi, ${ }^{2}$ Departemen Orthopaedi dan Traumatologi Fakultas Kedokteran Universitas \\ Padjadjaran/Rumah Sakit Dr. Hasan Sadikin, ${ }^{3}$ Departemen Ilmu Kesehatan Masyarakat Fakultas Kedokteran \\ Universitas Padjadjaran
}

\begin{abstract}
Abstrak
Infeksi kecacingan yang disebabkan oleh soil transmitted helminth (STH) dapat mengakibatkan gangguan gizi dan menurunkan kualitas sumber daya manusia. Imunitas terhadap infeksi cacing mengaktifkan respons Th2 yang ditandai oleh peningkatan kadar interleukin-4. Penelitian ini bertujuan mengetahui kadar IL-4 pada anak kecacingan dan yang tidak kecacingan serta menganalisis validitas pemeriksaan IL-4 sebagai indikator infeksi kecacingan. Sebanyak 74 sampel plasma EDTA diambil dari anak-anak kelas 1-3 SD di Kecamatan Jatinangor kemudian dilakukan pemeriksaan kadar IL-4 dengan metode ELISA. Hasil penelitian didapatkan kadar IL-4 pada subjek yang terinfeksi kecacingan lebih tinggi secara bermakna dibanding dengan subjek yang tidak terinfeksi $(3,001 \mathrm{pg} / \mathrm{mL}$ berbanding $1,406 \mathrm{pg} / \mathrm{mL} ; \mathrm{p}<0,001)$. Pada cut-off point 1,585 pg/mL, kadar IL-4 memiliki sensitivitas $66,7 \%$, spesifisitas $65,9 \%$, dan akurasi $66,2 \%$. validitas instrumen pemeriksaan telur cacing berdasarkan pemeriksaan kadar Interleukin-4 termasuk kategori cukup dengan koefisien K (Kappa) sebesar 0,635. Kadar IL-4 pada subjek yang terinfeksi kecacingan meningkat 1,6 kali lebih tinggi dibanding dengan subjek yang tidak terinfeksi kecacingan. Simpulan, IL-4 merupakan pemeriksaan yang valid digunakan sebagai diagnostik infeksi kecacingan. [MKB. 2016;48(4):211-5]
\end{abstract}

Kata kunci: Infeksi kecacingan, interleukin-4, uji validasi

\section{Interleukin-4 (IL-4) Level Validation Testing as A Helminthiasis Infection Diagnostic Testing Alternative}

\begin{abstract}
Helminth infection caused by soil transmitted helminths (STH) could be one of the reasons for malnutrition, impaired growth, and intelligence which will reduce the quality of human resources. Helminth infections are potent inducers of Th2 type responses as well as increased secretion of interleukin-4. The purpose of this study was to determine the interleukin-4 concentration in subjects with helminth infection and without helminth infection and to assess the validity of the plasma Interleukin-4 concentration assessment in helminth infection patients. This study examined 74 plasma samples from 1st-3rd grade elementary students in Jatinangor district using ELISA method. The results indicated that IL-4 concentration of helminth infection subjects was significantly higher compared to that of non-infected subjects $(3.001 \mathrm{pg} / \mathrm{mL}$ vs $1.406 \mathrm{pg} / \mathrm{mL}, \mathrm{p}<0.001)$. A cut-off point of $1.585 \mathrm{pg} / \mathrm{mL}$ for IL-4 concentration means $66.7 \%$ sensitivity, $65.9 \%$ specificity, and $66.2 \%$ accuracy . The validity of the helminth ova assessment instrument based on Interleukin-4 level testing is fair with a K (Kappa) coefficient of 0.635 . The IL-4 level in helminth infection patient increased 1.6 times compared to non-infected subjects. In conclusion, IL-4 is a valid marker for diagnosing helminthiasis. [MKB. 2016;48(4):211-5]
\end{abstract}

Key words: Helminth infection, Interleukin-4, validity test

Korespondensi: Ike Hermawati, M.Kes, STIKes A. Yani Cimahi Jalan Terusan Jenderal Sudirman Cimahi 40633, mobile 085624475008, e-mail nuha_hanifa@yahoo.com 


\section{Pendahuluan}

Penyakit kecacingan ialah infeksi kronik yang menginfeksi masyarakat dalam jumlah yang cukup tinggi. Sebagai upaya pengelolaan dan pengendalian untuk dapat mengeradikasi suatu penyakit adalah dengan menegakkan diagnosis yang pasti. Metode Kato-Katz merupakan metode standar yang paling banyak dilakukan dan masih merupakan metode yang direkomendasikan oleh Depkes dan WHO untuk pemeriksaan telur cacing karena metode ini relatif murah dan sederhana. Kelemahan pada metode ini adalah diperlukan waktu yang lama dalam pengerjaannya serta sensitivitas yang rendah sehingga memberi peluang terjadi hasil pemeriksaan negatif palsu (false negative). Diperlukan alternatif diagnostik yang dapat dilakukan secara automasi dan juga sensitivitas yang lebih baik, salah satunya dengan teknik imunodiagnosis menggunakan metode ELISA. Imunitas terhadap infeksi cacing nematoda adalah salah satu infeksi yang mengaktifasi respons humoral yang ditandai oleh peningkatan suatu kadar Interleukin-4, IL-5, IL-10, dan IL-13. Sitokin-sitokin ini akan menyebabkan aktifasi T-helper ke arah Th2 untuk mengaktifkan respons imun humoral, responss imun dengan aktivasi Th2 akan diproduksi lebih banyak IL-4. Dari sitokin-sitokin tersebut, IL-4 disebut sebagai prototipe sitokin Th2 yang mengakibatkan predominan humoral dengan cara menekan respons imun seluler sehingga pada infeksi kecacingan semestinya kadarnya akan meningkat jauh di atas normal. Penelitian ini dilakukan untuk lebih memahami perbedaan kadar IL-4 pada anak kecacingan dan yang tidak kecacingan, serta menganalisis validitas pemeriksaan IL-4 metode mikro ELISA sebagai indikator infeksi kecacingan.

\section{Metode}

Dilakukan studi cross-sectional pada siswa SD golongan usia yang rentan terkena kecacingan, yaitu usia 6-9 tahun dengan kriteria mendapat izin dari orangtua untuk ikut serta dalam penelitian dengan menandatangani persetujuan ikut dalam penelitian atau informed consent, tidak sedang dalam kondisi sakit dan tidak mengonsumsi obat cacing dalam kurun waktu 6 bulan terakhir di Kecamatan Jatinangor selama bulan Juli-Agustus 2014. Bahan pemeriksaan berupa feses yang diperiksa mempergunakan metode Kato-Katz dan darah EDTA diambil sebanyak $1 \mathrm{~mL}$, lalu disentrifus pada kecepatan
3.000 rpm selama 10 menit dan dipisahkan plasmanya. Metode pemeriksaan pada kadar IL-4 dilakukan mempergunakan enzyme linked immunosorbent assay (ELISA). Pengambilan bahan pemeriksaan untuk feses dilakukan di rumah masing-masing kemudian diserahkan kepada petugas laboratorium untuk diperiksa, sedangkan untuk pengambilan darah dilakukan di sekolah. Ukuran sampel ditentukan dengan pendekatan statistik uji validasi didapatkan jumlah sampel 74 yang terdiri atas 2 kelompok subjek yang terinfeksi kecacingan dan tidak.

Analisis statistik penelitian mempergunakan uji normalitas Kormogorov-Smirnov yang dapat menggambarkan distribusi karakteristik penelitian. Analisis statistik pada penelitian ini terdiri atas uji nonparametrik Mann-Whitney untuk membandingkan kadar IL-4 pada yang terinfeksi kecacingan dan tidak, uji validitas instrumen dengan uji Kappa. Penentuan nilai cut-off point kadar IL-4 dengan cara menghitung sensitivitas, spesifisitas dan akurasi, sedangkan untuk dapat menghitung reliabilitas digunakan uji Kappa Indeks dengan receiver operating characteristics (ROC).

\section{Hasil}

Selama kurun waktu penelitian diperoleh 74 subjek yang terdiri atas 30 subjek terinfeksi kecacingan dan 44 tidak terinfeksi. Subjek penelitian berusia 6-9 tahun pada kedua kelompok dengan median usia subjek 8 tahun. Menurut jenis kelamin dari 32 orang anak laki-laki yang diperiksa 13 di antaranya positif kecacingan dan dari 42 orang anak perempuan ada 17 orang yang positif kecacingan.

Berdasarkan hasil uji nonparametrik MannWhitney terdapat perbedaan yang bermakna kadar IL-4 antara subjek yang terinfeksi kecacingan dan tidak terinfeksi $(3,001 \mathrm{ng} / \mathrm{mL}$ dengan $1,406 \mathrm{ng} / \mathrm{mL} ; \mathrm{p}<0,001$ )

Analisis kurva ROC dengan area under curve (AUC) 0,72 didapatkan nilai cut-off point kadar IL-4. Terlihat kadar IL-4 pada beberapa nilai cut-off point memiliki beberapa sensitivitas dan spesifisitas (Gambar).

Hasil uji validitas didapatkan kadar IL-4 dan cut-off point 1,585 ng/mL memiliki sensitifitas sebesar 66,7\%, spesivisitas 65,9\%, NDP 57\%, NDN 74\%, dan akurasi 66,2\%.

Validitas pemeriksaan IL-4 metode mikro ELISA sebagai indikator infeksi kecacingan. diketahui bahwa 35 subjek dengan kadar IL-4 lebih dari $1,585 \mathrm{pg} / \mathrm{mL}, 20$ di antaranya positif 


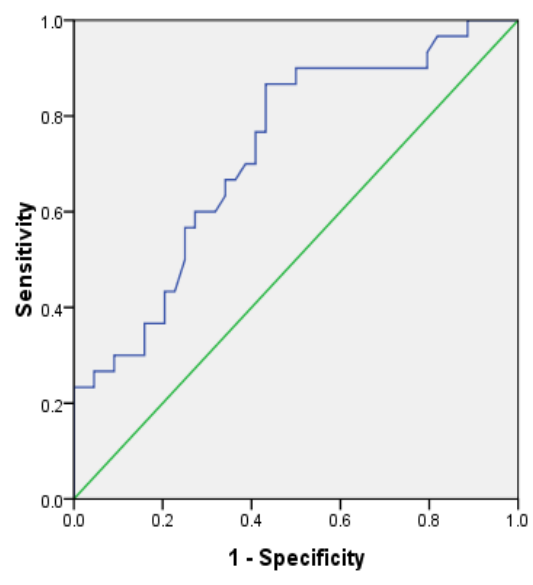

Diagonal segments are produced by ties.

\section{Gambar}

kecacingan dan 15 negatif kecacingan. 39 subjek dengan kadar IL-4 kurang dari 1,585 pg/mL, 10 di antaranya positif kecacingan dan 29 negatif kecacingan.

Hasil uji statistik didapatkan nilai $\mathrm{p}=0,006$ $(<0,05)$ berarti ada hubungan yang signifikan antara nilai cut-off kadar IL-4 (1,585 pg/mL) dan kejadian Infeksi kecacingan.

Konsistensi penilaian kedua pemeriksaan yaitu pemeriksaan Kato-Katz dan pemeriksaan IL-4 terlihat bahwa nilai kappa adalah 0,653 yang termasuk dalam kategori kesesuaian yang cukup (fair) antara baris dan kolom $(\mathrm{p}=0,006)$.

\section{Pembahasan}

Pemeriksaan pada kadar IL-4 diharapkan memiliki kelebihan, yaitu lebih sensitif untuk pemeriksaan kecacingan bila dibanding dengan metode konfensional dengan waktu pengerjaan yang singkat untuk pemeriksaan dalam jumLah yang cukup banyak.

Jumlah subjek laki-laki yang telah terinfeksi

Tabel 1 Perbandingan Kadar IL-4 pada Infeksi Kecacingan

\begin{tabular}{cccc}
\hline \multirow{2}{*}{$\begin{array}{c}\text { Kadar } \\
\text { IL-4 }\end{array}$} & \multicolumn{2}{c}{ Infeksi Kecacingan } & Nilai \\
\cline { 2 - 3 } & Positif (30) & Negatif (44) & p \\
\hline Rata-rata & 3,001 & 1,406 & \\
Median & 1,875 & 0,955 & 0,001 \\
Rentang & $0,490-9,050$ & $0,360-4,85$ & \\
\hline
\end{tabular}

Tabel 2 Sensitivitas dan Spesifisitas Kadar IL-4 Metode ELISA

\begin{tabular}{ccccc}
\hline $\begin{array}{c}\text { Kadar } \\
\text { IL-4 } \\
\text { (ng/mL) }\end{array}$ & \multicolumn{2}{c}{$\begin{array}{c}\text { Infeksi } \\
\text { Kecacingan }\end{array}$} & Total & Nilai p \\
\cline { 2 - 3 } & Positif & Negatif & & \\
\hline$>1,585$ & 20 & 15 & 35 & 0,006 \\
$\leq 1,585$ & 10 & 29 & 39 & \\
Total & 30 & 44 & 74 & \\
\hline
\end{tabular}

Keterangan: Sensitivitas: 66,7\%, spesifisitas: 65,9\%, akurasi: 66,2\%, Kappa Indeks: 0,653 (95\% KI: 1,448 sampai 10,326 )

kecacingan lebih sedikityaitu 13 orang dibanding dengan perempuan 19 orang. Keadaan ini sejalan dengan penelitian yang dilakukan oleh Kharis pada anak sekolah dasar di Banjarbaru. Anak perempuan berisiko 1,1 lebih tinggi menderita infeksi cacing dibanding dengan anak laki-laki. ${ }^{20}$

Usia juga merupakan salah satu faktor yang berpengaruh terhadap infeksi kecacingan. Risiko terinfeksi kecacingan pada usia anak-anak relatif masih tinggi, yaitu pada usia 6-9 tahun. Menurut kelompok usia, anak usia 6-9 tahun lebih sering terinfeksi cacing dibanding dengan anak yang berumur 10-15 tahun. ${ }^{2}$ Sasongko $\mathrm{dkk}^{3}$ juga menyebutkan di dalam penelitiannya di Bali prevalensi infeksi cacing paling tinggi terjadi pada anak usia 0-9 tahun. Hasil ini dapat dihubungkan dengan tingginya aktivitas bermain ditanah dan pengawasan terhadap higiene dan sanitasi terhadap diri sendiri masih sangatlah kurang sehingga risiko terinfeksi oleh telur atau larva cacing menjadi lebih besar.

Tabel 1 menunjukkan kadar IL-4 rata-rata pada subjek yang terinfeksi kecacingan lebih tinggi 1,6 kali dibanding dengan yang tidak kecacingan, yaitu $3,00 \mathrm{pg} / \mathrm{mL}$, median 1,875 $\mathrm{pg} / \mathrm{mL}$, rentang 0,490-9,050 pg/mL, sedangkan pada subjek yang tidak terinfeksi memiliki ratarata $1,406 \mathrm{pg} / \mathrm{mL}$, median $0,955 \mathrm{pg} / \mathrm{mL}$, rentang 0,360-4,85 pg/mL. Keadaan ini bahwa apabila kadar IL-4 meningkat 1,6 kali dapat dikatakan terdapat kecurigaan terhadap infeksi kecacingan. Penelitian ini sejalan dengan hasil penelitian yang dilakukan Mahaty dkk. ${ }^{12}$ yang menyatakan terjadi peningkatan kadar IL-4 pada subjek yang terinfeksi kecacingan dibanding dengan yang tidak kecacingan.

Hasil uji Mann-Whitney pada taraf signifikasi 95\% menunjukkan perbedaan yang bermakna kadar IL-4 pada subjek yang terinfeksi dan tidak terinfeksi kecacingan (Tabel 2) dengan nilai $\mathrm{p}=0,001$ yang berarti ada perbedaan yang 
bermakna kadar IL-4 subjek yang terinfeksi kecacingan dengan tidak kecacingan. Apabila kadar Il-4 pada subjek $>1,585 \mathrm{pg} / \mathrm{mL}$ maka ada kemungkinan seseorang terinfeksi kecacingan dengan tetap mempertimbangkan gejala-gejala klinis serta keterangan klinis yang diperoleh dari penderita tersebut. Beberapa penelitian menyatakan infeksi kecacingan merangsang respons Th2 dengan ditandai peningkatan kadar IL-4 dan sitokin-sitokin Th2 lainnya. ${ }^{6,8,17,19}$ IL-4 juga diperlukan karena berperan dalam ekspulsi cacing melaui aktivasi jalur sinyal intraseluler STAT6 dengan cara meningkatkan sekresi mukosa usus, meningkatkan kontraktilitas otot halus usus, dan menyereksi cairan ke dalam lumen usus. ${ }^{11}$

Berdasarkan atas Tabel 3 terlihat bahwa pemeriksaan kadar IL-4 pada cut-off point $1,585 \mathrm{pg} / \mathrm{mL}$ sebagai salah satu penanda infeksi kecacingan karena dengan kadar tersebut didapatkan sensitivitas dan spesifisitas yang lebih tinggi dibanding dengan kadar Il-4 yang lain. Kadar IL-4 dengan cut-off point 1,585 pg/ $\mathrm{mL}$ menggambarkan peningkatan kadar IL-4 yang disebabkan oleh cacing dalam tubuh yang telah merangsang perkembangan respons imun tubuh ke arah humoral. Hasil penelitian ini menunjukkan nilai akurasi pemeriksaan kadar IL-4 pada kecacingan adalah $66,3 \%$, sedangkan nilai sensitivitas dan spesifisitasnya tergolong sedang, yaitu $66,7 \%$ dan $65,9 \%$. Nilai ini sama jika dibanding dengan pemeriksaan feses metode Kato-Katz yang memiliki nilai sensitivitas yang sedang (70\%) akan tetapi untuk kasus tertentu seperti intensitas kecacingan yang rendah maka nilai sensitifitas metode tersebut akan semakin rendah.

Terlihat nilai kappa adalah 0,653 yang termasuk dalam kategori kesesuaian yang cukup (fair) antara baris dan kolom. Hal ini berarti ada kesesuaian yang cukup pemeriksaan telur cacing menggunakan metode Kato-Katz dengan pemeriksaan IL-4.

Nilai probabilitas (Approx Sig) adalah 0,006 atau di bawah 0,05. Hal ini berarti ukuran Kappa tersebut signifikan atau dapat dikatan ada kesesuaian antara pemeriksaan telur cacing menggunakan metode Kato-Katz dan pemeriksaan IL-4.

Penelitian ini mendapatkan nilai sensitivitas $66,7 \%$ dan juga nilai spesivisitas $65,9 \%$. Suatu alat pemeriksaan untuk mendiagnosis suatu penyakit diharapkan memenuhi uji diagnostik yang ideal, yaitu mempunyai nilai sensitivitas dan spesifisitas yang tinggi, tetapi tidak semua alat pemeriksaan dapat memenuhi uji diagnostik yang ideal. Menurut Mayer dkk. berdasarkan evidence based science bahwa uji penapisan suatu penyakit alat pemeriksaan diharapkan memiliki sensitivitas $\geq 98 \%$ dan spesifisitas $\geq 74 \%$, sedangkan untuk mendiagnosis suatu penyakit diharapkan memiliki nilai sensitivitas $\geq 64 \%$ dan nilai spesifisitas $\geq 98 \%$. Parameter suatu pemeriksaan yang dibutuhkan para klinisi adalah NDP (nilai duga positif) dan NDN (nilai duga negatif) bila dibanding dengan sensitivitas dan spesifisitas untuk mengetahui interpretasi terhadap hasil dari pemeriksaan yang sudah dilakukan. Hasil penelitian ini memperlihatkan bahwa pemeriksaan ini memiliki NDP 57\% dan NDN 74\%.

Simpulan, penelitian ini juga dapat dijadikan alternatif pemeriksaan kecacingan mengingat pemeriksaan telur cacing mempergunakan cara konvensional menemukan telur cacing pada feses karena semakin ringan intensitas kecacingan maka semakin sulit untuk ditemukan. Semakin berkurangnya tenaga laboran di lapangan maka pemeriksaan serologis dapat menjadi salah satu alternatif diagnosis kecacingan.

\section{Daftar Pustaka}

1. Natadisastra D, Agoes R. Parasitologi kedokteran: ditinjau dari organ tubuh yang diserang. Jakarta: EGC; 2009.

2. Hairani B, Annida. Intestinal parasite incidence on elementary school student in town and village at tanah bumbu district. Jurnal Buski. 2012;4(2):102-8.

3. Sasongko A, Irawan HSJY, Tatang RS, Subahar R, Purnomo, Margono SS. Intestinal parasitic Infections in primary school children in Pulau Panggang and Pulau Pramuka, Kepulauan Seribu. Makara Seri Kesehatan 2002;6(1):8-11.

4. Knopp S, Salim N, Schindler T, Voules D, Rothen J, lweno 0, dkk. Diagnostic accuracy of Kato Katz, FLOTAC, Baermann, PCR Method for the detection of light-intensity Hookworm and Strongyloides stercoralis infection in Tanzania. Am J Trop Med Hyg. 2014;90(3):535-45.

5. Kuby J. Immunology. New York: Freeman and company: 2000

6. Mendez P. Immunological mechanisms by which concomitant helminth infection predispose to the development of human tuberculosis. Korean J Parasitol. 2012; 50(4): 281-6.

7. Cooper PJ, Chico ME, Sandova C, Espinel 
I, Guevara A, Kennedy MW, dkk. Human infection with Ascaris lumbricoides is associated with a polarized cytokine responsse. J Infect Dis. 2000;182:1207-13.

8. Figueiredo CA, Barreto ML, Rodrigues LC, Cooper PJ, Silvia NB, Amorim LD, dkk. Chronic Intestinal helminth infection are associated with immune hyporesponssiveness and induction of a regulatory network. Infect Immun. 2010;78(7):3160.

9. Maizels RM, Balic A. Resistance to helminth infection: the case for IL-5 dependent mechanisms. J Infect Dis. 2004;190(3):4279.

10. Ohnmacht C,Voehringer D. Basophil effector function and homeostasis during helminth infection. Blood. 2009;113(48):2816-25.

11. Herbst T, Esser J, Prati M, Kulagin M, Stettler R, Zaiss MM, dkk. Antibody and IL-13 support helminth induced basophil expansion. PNAS. 2012;109(37):14954-5959.

12. Mahatty S, Abraham JS, King CL, Limaye AP, Nutman TB. Pararel Regulation of IL-4 and IL-5 in human helminth infection. J Immunol. 1992;148(11):3567-71.

13. Mcsorley HJ, Maizels RM. Helminth infections and host immune regulation. Clin Microbiol Rev. 2012;25(4):585-608.

14. Smith HH, Everts B, Hartger FC,Yazdanbakhsh
M. Chronic Helminth infection protect againt allergic disease by active regulatory processes. Springer. 2010;10(1):3-12.

15. Wahyuni S. General Introduction: Helminth infections, allergic disorders and immune responsses, studies in Indonesia. [Dissertation] Netherland: Leyden University; 2006.

16. Allen JE, Maizels RM. Diverity and dialogue in immunity to helminth. Nat Rev Immunol. 2011;11(6):375-88.

17. Maizels RM, Yazdanbakhsh M. Immune regulation by helminth parasites: cellular and molecular mechanisms. Nat Rev Immunol. 2003;3(9):733-44.

18. Maizels RM, Hewitson JP, Smit KA. Susceptibility and immunity to helminth parasites. Current Opinion Immunol. 2012; 24(4):459-66.

19. Moreau E, Chauvin A. Immunity against helminths: interactions with the host and the intercurrent infections. J Biomed Biotechnol Hindawi Publishing Corporation; 2010.

20. Faridan K, Marlinae L, AlAudhah N. Faktorfaktor yang berhubungan dengan kejadian kecacingan pada siswa Sekolah Dasar Negeri Cempaka 1 Kota Banjarbaru. Jurnal Buski. 2013; (4).3:121-7. 